\title{
Recollections of Pioneer Lawmakers of Iowa
}

\section{By Davm A. Dancer, Secretary}

The reminiscences of over twenty-five years in high office by one of Iowa's most distinguished public servants, the dramatic story of the return of a Republic of Alabama flag seventy-five years after its capture by Iowa troops in the Civil war, and a perceptive examination of our contemporary values by a former governor of Iowa highlighted the Thirty-fifth biennial session of the Pioneer Lawmakers of Iowa Association held in Des Moines March 26, 1959. As has happened several times in the past, the day was rainy and generally disagreeable, probably preventing some members from attending. But some thirty-one men who played a part in framing the laws of the state signed the register that was first used at the Fourth session in 1894.

The meeting was called to order at 10 o'clock in the Dodge Room of the State Historical Building by the president, Judge Harold E. Davidson. Reverend Wayne L. Carlson, pastor of the First Methodist Church at Ida Grove, gave the invocation.

President Davidson: Two years ago I had the honor to substitute for the outgoing president, Frank Shane, who was ill. I also had the opportunity, the pleasure and the honor of presenting the governor at that time. $\mathrm{He}$ has been kind enough to greet us again with a few words of welcome. Our governor, Mr. Loveless.

Gov. Herschel Loveless: Thank you, and thank you, Judge. Good morning, Pioneer Lawmakers. In this year 1959, it is again a privilege to extend greetings to you. I think it rather superfluous that I do because each of you feels very much at home in this area on top of the Hill; and I am sure that in the hours of this day you will find that you have been made very welcome by lots of folks other than myself.

I could offer an apology for the weather; however, I had very little to do with it, as you well know. I can only take credit for the good and disclaim any responsibility for the bad. I recognize that it has created a problem for a lot of you in coming in. At this time of March, with the possibility of the 
rain getting real white and slick before it quits, I think maybe it is an exercise of good judgment not to gamble too extensively on the weather.

I say with a great deal of sincerity that individually and collectively, in terms of the public service that you have rendered in past legislative sessions, you can take some degree of pride in Iowa's development, her economy, and the position we now occupy in this nation of soon to be 50 states. The soundness of legislation enacted over a period of years has kept us up in the top echelon of states from the standpoint of personal income growth and fiscal position as a state.

So as you walk into the legislative halls today I think you can well hold your head high in saying, to yourselves at least, that you had a part in it. I can only hope that you can meet together a multitude of times, reminiscing and recalling some of your experiences and accomplishments. I am sure that you will.

I could be real critical of the boys across the street in not holding up the activities of yesterday as an example for today. You may have found them quite interesting. I am far removed from the No Man's Land on the second floor, but the blow-byblow accounts from the Legislative Assembly that filter down to my office seem to indicate considerable discussion; and I think that is good.

The things of controversy are the things that are most generally worth while, as they are brought out, aired and debated. You will find the will of the prevailing majority the thing that makes this democracy work rather well. I think all the world's problems could well be solved on the same basis if we had the means of communication and negotiation provided by our legislative halls and legislative procedure under democracy.

I would like to wish you individually the very best of good health and happiness in the coming years, and with a lot of humility, to thank you for the opportunity again this year to come before you and very briefly say to you what the people of your home areas would if they were to think of it: that you have served well as public servants. They appreciate the service that you did render and individually wish you the very best.

So good luck to you.

President Davidson: We will now have a response to the Governor's address of welcome by Hon. Blake Willis from Perry.

Mr. Willis: Governor, members of the General Assembly who are here, and friends. It certainly is a pleasure to be able to get together and meet our old friends in what is perhaps the most exclusive organization in the State of Iowa. We first 
have to get the electors to vote for us to get to the General Assembly, and then by the grace of God we have to live 20 years before we can get in.

I know that when we were in the legislature we felt that our problems were burdensome. We felt many times that legislation wouldn't correct the things we were up against; but those problems have increased in number and have become more difficult to solve. We know that the present legislators have done a wonderful job in presenting to the legislature the many bills. So oftentimes, as we all know, somebody has an important bill in his pocket that never gets to the legislature. I think we can say that this legislature has brought out in the open the important bills and have discussed them thoroughly. I know we the public are more satisfied when bills are brought to the attention of the legislature than when held in a committee.

During the past month I had the pleasure of being in Hot Springs, close to the 62nd General Assembly of the State of Arkansas. I want to tell you folks that we have a good legislature here.

I wish to thank you for this day, and thank you, Governor, very much for your words.

President Davidson: Thank you, Governor, for coming.

At this time in the proceedings it is customary to appoint a nominating committee to suggest and nominate officers for the next biennium. I have put back on this committee one of our old and beloved friends who has been around this State House for many, many years; and I suspect knows as many if not more of the Pioneer Lawmakers of Iowa than any other one of us. So the chairman of this committee will be the Honorable Emory English; and I should like to appoint on that committee with him former Senator Claude Stanley and former Senator Augustine from Oskaloosa.

\section{Recollections of Congressman LeCompte}

Now it provides here for an address by me. I do not think that I should take the time this morning to make any particular address as I did two years ago when I acted in that capacity both here and over in the State House in the afternoon. I know we have some distinguished gentlemen on this program that we would very much like to hear from, more or less in the way of reminiscences.

When I first came to the legislature right after World 
War I, I was the only member of the house that didn't have a civilian suit. I came in a uniform. On the opposite side of the hall there was a distinguished senator who was in a similar situation. Until we got our first pay checks we didn't wear civilian clothes. That senator served with distinction not only in the Iowa house, but later went to Congress, and he just concluded at the beginning of this year 20 years of service in the United States Congress. I think that is quite a distinguished service career in legislation, both in the state and in our national house.

So at this time I am sure we would all very much enjoy hearing from our distinguished colleague and friend, the Hon. Karl M. LeCompte of Wayne county.

Mr. LeCompte: Thank you, Judge Davidson, friends and colleagues of days gone by. This is a pleasure indeed to be here with you folks.

I was here in the Thirty-seventh General Assembly, but my introduction to the Iowa legislature came in 1911. At that time there was a deadlock over the election of a United States Senator. The deadlock occurred early in January when the General Assembly met. I was just recently out of college, about two or three years, and like most young men was intrigued by politics and excited about that contest.

But after they had voted half a dozen times in six days, I took down with a terrible attack of typhoid fever-it's a bad disease now and it was a terrible disease then. When I got up again it was about the first of April and the deadlock was still on. The General Assembly had been in controversy trying to elect a United States Senator from the day the legislature convened until almost the day of adjournment.

Senator Francis has written a delightful and readable story entitled "The Last Election by the Legislature," the last election of a United States Senator by the legislature. At the close of that article he raises the question mildly if we have gained anything in the stature of our senators by electing them by the people. 
I got better from my disease and my father told me to take a vacation, come to Des Moines, visit the legislature and spend several days recuperating from the illness. So I came over and met our senator, Dr. George McCulloch-long dead-and with him marched from the senate chamber over to the house to a joint session where a roll call was taken. That contest, as I recall, was chiefly between Senator Kenyon and Senator Lafe Young, who divided the Republican vote for days and weeks. I think the Democrats, who had a substantial number but were in the minority, voted mostly for the late Claude Porter; and there the legislature hung until almost the day of adjournment. When they did get together they compromised and elected Senator Kenyon; and he started on his great career, 10 or 12 years in the senate and then a federal judge before he died.

Six years later I was a member of the senate of Iowa. I little thought of going to the senate when I visited the legislature for the first time in 1911, but in 1917 I was there. We had trouble over road legislation in an effort to do something toward getting Iowa out of the mud, but the legislature turned down all bills, and I was a part of it. We wouldn't allow a cent for paved highways. Now a legislature might be run out of the state if it wasn't in favor of good roads, but that was the story then.

\section{EXPERIENCES IN CONGRESS}

Permit me, if I may, to tell you of one or two incidents that came my way in Washington.

As a member of the joint committee on the Congressional Library I had close contacts with the librarian, and particularly Dr. Luther Evans, who is now in Paris helping in the NATO headquarters. He called me one day in February and said, "Day after tomorrow will be Lincoln's birthday. I am having a luncheon in my office and I would like to have you come over to it."

"Well," I said, "Dr. Evans, I guess I will be glad to 
come." I had thought I would take my office staff to lunch that day, but I hadn't said anything to them about it and I knew I could take them some other time. So I said, "I will be there unless something else makes it impossible to come."

He said, "I wish you would make a special effort to be there because of two facts: I am going to have a very distinguished guest at the luncheon, and I am going to present to the three or four folks that are there some things that the public has never seen, some Lincoln relics." He said, "I have in a box all of the things that President Lincoln had on his person and in his pocket the night he was shot in Ford's Theater."

Our luncheon started between $12: 30$ or 1:00, and it lasted until 4:00 o'clock in the afternoon. Besides myself, he had Senator Greene from Rhode Island, who is over 90 years of age but a very active man. He occupied a corresponding position in the senate to the one which I had in the house. The very important guests were General Gruenther and General Dwight D. Eisenhower.

The four of us, and someone else whom I don't recall, sat there until 4:00 o'clock in the afternoon going over the Lincoln items and talking about Lincoln. General Eisenhower, who became President of the United States the next year, is a great student of the Civil War and the Reconstruction period. And so is General Gruenther who was his close right-hand man at all times.

That was the closest and the longest that I have ever been with the president. However, I have had occasion to meet him, and once I asked him if he remembered the time Dr. Evans opened the Lincoln material: his glasses, his knife, his watch, his watch chain, and strangely enough, a Confederate bill. Lincoln had very little money in his pocket. He didn't need any, of course, because he was taken to the theater in a carriage, someone else having made full arrangements. That is the way a president travels or does anything; but Lincoln did have a Confederate bill. 
Dr. Evans expressed the opinion that perhaps the president had a reception that afternoon. The war was over, the bill was worthless, of course, and perhaps somebody at the reception had said, "Here, Mr. President, is a nice souvenir you better have." And perhaps he in a quick way had said, "Thank you very much. That is a good thing to keep."

Dr. Evans said it certainly had no significance. President Lincoln was not hoarding money, and gathering worthless Confederate money. But the night Lincoln was shot he did have a Confederate bill in his pocket.

I have had some interesting experiences down through the years. I stopped in Chicago one time when the Democratic national convention was in session, and met the late Charley Needham from Grinnell. He insisted that we go over to the headquarters of Harry Hopkins. Harry Hopkins was in control of the Democratic convention that year. Charley had known Harry Hopkins in Grinnell. I had only met him; I wasn't acquainted with him. When we went in, his outer office was full but Charley persuaded one of the clerks there to tell Mr. Hopkins that he was there with a friend from Iowa, and immediately we were ushered in to see Mr. Hopkins, while the mayor of Chicago and other people were cooling their heels.

He took us to his back bedroom where he sat on the edge of the bed, and he and Charley talked for 20 or 30 minutes I know without a doubt. Charley had been a pall-bearer at his father's funeral.

Outside, men waited to see him. From time to time the clerk came to the door and said so-and-so was outside. "It makes no difference," Mr. Hopkins said, "I am busy here now. Tell him to wait."

He said in the course of his remarks, "We are going to nominate President Roosevelt for a third term if we don't have any trouble, but I am telling every one of these fellows, if you buck on the platform, if you buck on the nominee for vice-president, if you are not happy about the whole thing, the President will not accept the 
nomination. We can draft somebody who isn't known and lose the election; but if you want to win the election you do as I say."

He said that is what he told every man who came to him with any suggestion. The 1940 convention was Harry Hopkins' great moment. I never heard of him in connection with any of the others in any big way, but he ruled that convention. He had the power, and knew he had it, and didn't hesitate to exercise it.

This is a most enjoyable occasion. I have never been to a meeting of the statesmen of the rail fence era, as we might call it. One thing or another has always interfered with my getting here, but I want to say that it is a pleasure for me to be here with you. I remember well when I was in the legislature and I saw the Pioneer Lawmakers come over to the senate and the house. Down in my heart I felt sorry for those poor old men who, I said, were living in the past, "They are living on the glories of their old days."

But time is fleeting and it is always later than you think, so I am here with the Pioneer Lawmakers of Iowa, the statesmen who did things in the rail fence era. But we are not through yet. The role of an elder statesman can be, and is for me, a most enjoyable one, and I think a very important one. Very often the younger men, in spite of their best intentions, are influenced just a little by what seems to be popular. They have their careers before them. The elder statesmen who have no ambitions at all can do a great job of analyzing problems, seeing them in their true lights and explaining them to the public in a way that ambitious candidates cannot possibly do because they are frequently bound by the position of their party.

I think there is a great opportunity for service by the Pioneer Lawmakers for the benefit of the State of Iowa and for our country. We are going to meet and live in the future for a long time to come.

President Davidson: Thank you, Congressman LeCompte. 
I note I overlooked the Necrology report by our secretary. Dave Dancer, who as you know is the executive secretary of the Board of Regents of the State of Iowa, is a very very busy man, particularly so during the legislative session; but to him goes most of the credit for this meeting today and the arrangements of many of the facilities that we have enjoyed and will continue to enjoy during the day. I am sure he has a report, and perhaps some letters from some of our members that are unable to be present.

\section{NeCrology RePort}

Secretary Dancer read the names of those members who had passed away during the biennium:

\begin{tabular}{|c|c|c|c|}
\hline NAME & COUNTY & SERVICE & YEAR \\
\hline William G. Kerr & Grundy & R28-29 & 1900 \\
\hline Israel A. Smith & Decatur & R34 & \\
\hline Thomas J. B. Robinson & Franklin & S35-36 & 1913 \\
\hline James F. Johnston & Lucas & $\begin{array}{l}\text { R36-37-46 S39- } \\
\quad 40-40 \mathrm{Ex}\end{array}$ & \\
\hline F. A. Garber & Decatur & R37-38 & 1917 \\
\hline H. J. Mantz & Audubon & $\begin{array}{l}\text { R37-38 S39-40-40Ex } \\
\text { Judge District } \\
\text { Court 1925-1943 } \\
\text { Judge Supreme } \\
\text { Court 1943-1953 }\end{array}$ & \\
\hline Frank Oertel & Lee & $\begin{array}{l}\text { R37-38 } \\
\text { Judge Superior } \\
\text { Court } 1915-1957\end{array}$ & 1917 \\
\hline Leon Walter Powers & Crawford & $\begin{array}{l}\text { R38-39 } \\
\text { Judge Supreme } \\
\text { Court 1934-1936 }\end{array}$ & 1919 \\
\hline O. C. Sorlien & Humboldt & R38 & 1919 \\
\hline B. $\mathrm{B}$ & Bre & R39 & 1921 \\
\hline David Brittain & Madi & $\mathrm{R} 40-40 \mathrm{Ex}-41$ & 19 \\
\hline A. C. Noble & Muscatine & $\mathrm{R} 40-40 \mathrm{Ex}-41$ & 192 \\
\hline Theodore B. Stock & Alla & R40-4 & 192 \\
\hline Ellis & App & $\mathrm{S} 41-42-42 \mathrm{Ex}$ & 19 \\
\hline James D. Fleming & Crawford & $\mathrm{S} 41-42-42 \mathrm{Ex}$ & 192 \\
\hline O. E. Gunderson & Winn & S41-42-42Ex-43-44 & 192 \\
\hline Wm. E. McLeland & Marshall & $\mathrm{S} 41-42-42 \mathrm{Ex}-43-44$ & \\
\hline George Wesley Smith & O'Brien & $R 41-42-42 E x-43$ & 19 \\
\hline Joseph Wagner & & $R 41-42-42 E x$ & 19 \\
\hline L. O. Clark & Fremont & $\mathrm{R} 43$ & 19 \\
\hline Mrs. & Jackson & R43-44 S45-45Ex-46 & \\
\hline Lant H. Doran & Boone & S43-44-47-48 & \\
\hline
\end{tabular}




Gustave Alesch
T. G. Jensen
C. E. Lookingbill
T. W. Mullaney
Wm. Treimer
George W. Groves
James J. Gillespie
C. G. Good
Tom E. Murray
W. G. Wood
Lloyd Woods

\section{Plymouth}

R45-45Ex-46$46 \mathrm{Ex}-47-48-49$

Audubon

Story

R45-45Ex

R45-45Ex-46$46 \mathrm{Ex}-47$

Allamakee

O'Brien

$\mathrm{S} 45-45 \mathrm{Ex}-46$

R45-45Ex-46$46 \mathrm{Ex}-47$

Hamilton R46-46Ex-47

Polk S46Ex-47

Boone R47-49

Woodbury $\mathrm{S} 47$

Monroie R47-48

Clarke R47
1933

1933

1933

1933

1933

1935

1936

1937

1937

1937

1937

Thomas J. Guthrie Charles A. Dewey

THER THAN LEGISLATIVE

Polk $\quad$ Judge District Court 1916

Washington Judge District Court 1918

Judge U.S. District Court

1928

Ben F. Butler

Kenneth R. Cook

Osceola

Judge District Court

1926

Grover W. Brown

Paul H. McCoid

Mills

Page

Henry

Fredieric Magoun Miller Polk Judge District Court Judge District Court

1929 Judge District Court 1938 Judge Supreme Court 1938 Milton Joseph Glenn Dubuque Judge District Court 1939 The secretary also reported the names of a number of members from as far as Florida and California, who had written their regrets at being unable to attend.

President Davidson: I had written the next distinguished gentleman about appearing on the program this morning and am very glad to have him here this morning. I want to present to you my old friend, former Senator A. E. Augustine, from Oskaloosa.

Mr. Augustine: Well, as I look back at it, I came to the senate over there in '36. There were a lot of Democrats in there at that time. Then you know they began to get thinner, and thinner, and thinner. A few years later I began to notice the guard there at the door. Somebody would come in and he would point at them, and then I began to try to find out what it was all about. Well, those folks wanted to know what a Democrat looked like; he was a freak.

But you know actually I don't think it's changed a whole lot over there in the legislature. They are still talking about liquor by the drink over in the house. They do it every two years. They know it won't pass but it gives everybody a chance to make a speech for the benefit of the folks back home. 
And the senate is still talking about reapportionment. Gosh, that has been going on for a long, long while. You know I expect if we are back here in another 20 years the house would still be talking about liquor by the drink and the senate still talking about reapportionment, and they will both be talking about shooting the poor little turtledoves.

Republic of Alabama Flag

President Davidson: We have an interesting discussion coming up now from an old friend of mine who lives in an adjoining county from where I do. He is a lawyer and was in the legislature for a long time; he followed me in the office of Commerce Counsel of Iowa, and for his first six months and my last six months we cooperated and collaborated together in one of the largest rate cases ever held before the Interstate Commerce Commission of the United States, known as 28300 in the dockets. Later he became Assistant Attorney General of Iowa and served with distinction in that office. $\mathrm{He}$ is now back at Bedford in his home town with a leading law practice in that county. He is one of the finest lawyers in that district.

He was chairman of the military affairs committee in the legislature at the time it was discovered that Iowa had an Alabama flag. It had been obtained during the struggle between the states, the Civil War.

As I recall it, the members of the legislature decided that that flag should be returned to its native state, and the chairman of this committee headed the delegation that went to Alabama with that flag. I wish he would tell us something about it. I have heard him tell it, and to me his experiences on that occasion were very, very interesting.

I want to present to you the Hon. James A. Lucas of Bedford.

Mr. Lucas: It has been a long time since I have thought about that incident, until our president asked me to tell you something about it. It was an event which I have always remembered because of its simplicity and significance. I think this is rather an appropriate time to mention it because the Congress of the United States 
has recently, by joint resolution, created a committee for the observance of the Centennial of the Civil War starting in 1961. General U. S. Grant III, who is now retired, is the chairman of that committee.

Maybe some of you may know that Alabama seceded from the Union before the Confederacy was formed, and established a separate Republic of Alabama. The women in Montgomery made a flag for the Republic of Alabama, and flew it over the state house until, I believe, the Confederacy was formed later. The meeting for the formation of the Confederacy was also held in Montgomery.

About 1864 Wilson's Raiders, which was the 8th Iowa Cavalry Regiment, raided Montgomery and the flag was stolen from the archives. After the war a man by the name of Coons, who was a Cavalry veteran, presented it to the State of Iowa where it reposed in our archives for many years.

During the 48th session of our General Assembly in 1939, a request was made of Governor Wilson by Senator Lister Hill and Governor Frank Dixon of Alabama to return that flag. Our legislature passed a joint resolution for the return of the flag and voted an appropriation.

A committee was selected, of which Thomas Jefferson Noll was a member. His father had charge of the Grand Army of the Republic room in the State House for years; he was 94 years old and a veteran of the Illinois Union Regiment. Senator B. C. Whitehill of Marshalltown, a veteran of the Spanish-American War and chairman of the military affairs committee in the senate, and myself, a veteran of the First World War, made up the other committee members.

We left Des Moines about the 8th of March. We took our Civil War veteran, who was a very active little, redcheeked fellow. We got there the next day. We were guests at a buffet dinner at the home of one of the members of the legislature. We had dinner at the governor's mansion, attended an American Legion meeting, 
and heard an address by Chadwick, the national commander at that time. We also went out to Maxwell Field, the West Point of the Air Force as they called it.

The next day we were taken to the State House and met Paul Sanguinetta, a Confederate veteran who was born on the Island of Corsica, Napoleon's birthplace. He was a slim, short, bird-like 99-year-old who had served under Lee for four years.

They stopped us on the veranda of the State House at a bronze star imbedded, where Jefferson Davis took the oath of office as president of the Confederacy. They posed these two old fellows over this star shaking hands. Sanguinetta said to Noll, "At last, Yank, I have you as my prisoner." Noll said, "I don't know about that. You fellows tried that once and didn't get very far, and I don't think you could get the job done again."

Then they took us over to Jefferson Davis' old home, where a huge painting of him hangs in the drawing room. We stood there with the reporters, and our old Union veteran looked for a long time, finally turning around and saying, "Where is a picture of Abraham Lincoln?"

We went up the stairs, along a hall lined with people, to a joint session of the house and senate, where Senator Whitehill presented the flag. Governor Dixon accepted it.

A good many of those men had tears coursing down their cheeks. There was one Republican among a hundred members of the house and fifty members of the senate. His name was Senator Pitts and he came from the northwest corner of the State of Alabama. When Alabama seceded from the Union that county seceded from Alabama, and they raised a regiment of Union troops in that corner of Alabama.

After this joint session we were invited to a dinner where 300 members of the Daughters of the Confederacy were assembled in a state convention. Marie Bankhead Owen, who was a sister of the Speaker of the House at that time, presided over this banquet. She 
asked us for brief remarks which we gave, being very careful what we said. It wasn't the War of the Rebellion or the Civil War, it was the War between the States.

A woman had composed a song especially for the occasion, "My Land is a Red Land." At the conclusion of her song she stepped forward and presented an armload of red roses to our veteran, Thomas Jefferson Noll. The governor's wife got up and kissed him, and instead of docilely receiving her embrace he rose and put his arms around her and kissed her right on the mouth. He was a character.

But something tangible came out of that meeting. You know Decoration Day started in the South. It was proclaimed later in the North by General Logan as a day for the decoration of the graves of Union veterans. But up to the time of that meeting only the graves of Confederates had been decorated in the South on their Decoration day. At this convention a resolution was proposed and adopted, that hereafter the graves of Union veterans would be decorated at the same time as the graves of the Confederate veterans. At their national convention, the convention of all the states of the Confederacy held at Richmond that fall, Alabama proposed the same resolution for all the South; and it was adopted. So since then the graves of Union veterans have been decorated on their Decoration day.

The flag was taken back to its rightful resting place beneath the Southern skies where it belongs. It was first taken at a time when enmity and hatred were abroad in the land. It was returned in a spirit of affection and brotherly love. We hope, and we are sure, that its presence there will always remain as a symbol of the mutual feeling of sympathy and understanding that must remain between the people of two of our great states.

President Davidson: I am going to call on two or three more before the nominating committee gets back. I see a member in the audience who distinguished himself in the senate of this state. He is not only a splendid 
gentleman, but a great American. I would like to ask former Senator Stanley Hart if he won't make a few remarks.

Mr. Hart: Thank you, Judge.

This is my second attendance at a Pioneer Lawmakers biennial meeting. I qualified two years ago, having been elected in a special election to the 47th General Assembly in 1937. The session was half over when I was selected on the 10th of March to fulfill a vacancy created by the death of a Democratic senator. I came down and took my oath of office on St. Patrick's Day, the 17th of March. You can well imagine a green, 40-year-old country boy whose only parliamentary experience had been on a committee of the Chamber of Commerce, moving into the Iowa senate after the session was half over; and I inherited all the committees of my predecessor.

We had a state setup similar to what we have today. We had a Democratic governor, and a Democratic lieutenant governor, John Valentine, whom many of you will remember. The senate was Republican. I think my filling of the vacancy to which I succeeded gave us a 27-23 Republican majority. The house was organized Democratic.

I see Harry Weichman and other members of the Fortyseventh General Assembly here whom I possibly didn't become well acquainted with.

My experience was a very pleasant one. I served consecutively from ' 37 to ' 55 , and it was one of those great experiences that comes to a man but once in his lifetime, and I feel the richer and happier for it.

President Davidson: I would like to recognize my vice-president, Ray Yenter. I think he has a resolution.

\section{Walter H. Beam Honored}

Mr. Yenter: Mr. President, I do have a resolution which I would like to offer:

Whereas, One of our esteemed members of the Pioneer Lawmakers Association, Mr. Walter H. Beam, who also served as secretary of the organization, with distinction and honor, has suffered a severe illness; and

Whereas, He has rendered long years of public service in the employment of various state departments, including Secretary of the Senate; and

Whereas, $\mathrm{He}$ is incapacitated to the extent that he is 
no longer able to serve the people of Iowa in the manner which his previous record attests; Therefore

Be It Resolved by the Iowa Pioneer Lawmakers Association, gathered in biennial session on this 26th day of March, 1959, that we extend to Walter H. Beam our very best wishes for his complete recovery, and

Be It Further Resolved: That we assure him of our friendship and affection, due to the bond of interest and close association which has been established over a period of many years.

Mr. President, I move the adoption of the resolution.

President Davidson: Do I hear a second?

Mr. Willis: Seconded.

President Davidson: The motion has been made and seconded that we adopt this resolution. All in favor signify by saying "Aye." The motion is carried and the resolution is adopted and will be inserted in the records of this meeting.

Now if there is anybody else in the audience here who would like to say a word I am sure we would be glad to hear from him. Don't be bashful about it. I see Mr. Hauge back there. I served in the house with his father, and now it has been 20 years since he has been in there. Have you got something to say to us?

Mr. Hauge: I am a freshman in the Pioneer Lawmakers; and it is very hard for me to believe that Carroll Johnson and I served in the legislature 20 years ago. I was 53 years old yesterday.

I was very much interested in Jim's remarks about the Alabama flag, because Harry Weichman, Carroll Johnson and I were in the house at that time, and I believe I was on the military affairs committee. I had a burning desire to go to Alabama on that committee, but unfortunately they only sent the chairmen of the committees.

I was terribly impressed as a fairly young man to serve in the legislature from Polk county. That was the first session for quite a few that we had a Republican majority. I recall that because of the fact we had caucusies two or three times a week. I don't remember how much of a majority it was, but it was fairly substantial. Bob Blue, I think, was the floor leader, and we met in caucus constantly during that session. We expressed our own convictions and voted our convictions, 
but at the same time as a Republican group we stuck together.

We had a number of distinguished men such as Dean Peisen from Eldora and Martin Van Oosterhout, who is now a United States judge in St. Louis, we had some interesting characters. All in all, I thought that the Forty-eighth General Assembly, which was the first one that I was in, was a very interesting one.

I don't recall whether my father was a Pioneer Lawmaker or not. He served in three or four sessions and was chairman of the appropriations committee during the session the Rockefeller Foundation gave the money to the University of Iowa for the hospital at Iowa City on the condition that the state match the fund. I remember my father telling me about the appropriations committee meeting at the Savery Hotel. I think at one time he kept them there for three days and three nights in order to get the committee to recommend favorably the appropriation.

President Davidson: I see one of the distinguished citizens of Iowa standing in the back of the room. We should be glad to hear from a former Attorney General of Iowa, the Hon. George Cosson. I think you will remember him.

Mr. Cosson: It is eactly 50 years since I served in the Thirtythird General Assembly of Iowa in 1909 from the AudubonGuthrie-Dallas district, but don't think from the register that I am the oldest man.

I want to tell you for just a minute or two about the old days. You know the old fellows think those were the times; but there were giants in those days. I was elected county attorney on the ticket with Theodore Roosevelt. He was one of the great men of the world. He did things.

In those days we had Jonathan P. Dolliver down in the United States Senate, the man that drove Aldrich to the cloak room. Senator Warren of Wyoming came to the aid of Aldrich on Schedule $\mathbf{K}$, the wool tariff, and in discussion said that he did not own a single sheep. Senator Dolliver said in reply, "Why, I thought the Senator from Wyoming was the greatest shepherd since Abraham."

In referring to Taft, he said Taft was a very able gentleman surrounded by a body of men who knew exactly what they wanted, and remarked "The past year has witnessed two great events, each in itself a unique hoax. One was the discovery of the North Pole by Dr. Cook, and the other was the revision of the tariff downward by the Senator from Rhode Island, and the highest executive authority felicitated upon both occasions." He knew how to say things. 
We didn't have bi-partisanship in those days. Men said what they believed. We didn't have conformists, and a man said what he believed. Those were great times.

In the Iowa General Assembly, George W. Clarke, who had been speaker of the house, was lieutenant governor. John Hammill, Senator Adams, Smith F. Mitchell, Senator Saunders of Council Bluffs, and a number of very strong men were there.

I happened to play a modest part. I introduced nine bills and eight were signed by the governor. They included the red light injunction bill and the bill prohibiting unfair discrimination against poultry and eggs. After we got the bills through the senate, I was over in the house where John Sullivan was a representative from Polk county. He said, "That Cosson is over here in the house lobbying all the time." I didn't know a man could be a member of the General Assembly and a lobbyist at the same time, but I guess I was.

President Davidson: Mr. Joe Johnson, have you anything you want to say to us?

Mr. Johnson: I came in the Forty-first General Assembly after the first term of Governor Hammill. We didn't have a great many of the frills they have now. We didn't have a tax commission and we didn't have any social security; every man was on his own in those days. We enacted the first gasoline tax law that was finally signed. It was a two cent tax.

We tried hard to get a road control bill that session, but the supervisors didn't want to give up the hold that they had on the roads, and it was hard sledding. We did, however, get a certain sum set aside that the Highway Commission would have absolute control over. The next session, in the Fortysecond, we passed the first road control bill, and we thought the matter solved for all time. However, we find that since then it has become necessary to make certain revisions. Mr. J. A. King and Ray Yenter were in that first session.

The third session I was in, which was the Forty-third, we passed what was called the secondary road bill. That was bitterly contested at the time, but finally passed. A good many said they would appeal it the next session, but it proved so satisfactory that they didn't even introduce a bill to repeal it.

The income tax was discussed, but never got passed. However, I think it was in the Forty-third, too, that we set up the Tax Commission. For a number of years they had a small room down in the basement of the Capitol building. Later on they moved over to another building, and now I think they occupy at least two floors of the State Office building over here.

It was a very pleasant experience in the legislature. We 
had many fights, all good naturedly, and I wouldn't take anything for the experience that I had during those years.

ELECTION OF OFFICERS FOR 1959-1961

The chairman of the nominating committee, Emory H. English, submitted the following members of the association to serve as officers for the next biennium:

For President-Ray Yenter

For Vice-President-Stanley Hart

For Secretary-David Dancer

For Vice-Presidents by districts

First-Walter Dietz

Second-Ed Vrba

Third-E. P. Donohue

Fourth-A. C. Augustine

Fifth-Blake Willis

Sixth-Robert Blue

Seventh-R. G. Moore

Eighth-J. T. Dykehouse

The report was adopted and the nominees unanimously elected as presented by the committee.

The meeting adjourned at noon, and luncheon was served as in the past by the ladies of the Capitol Hill Christian church at east 12 th and Des Moines streets.

\section{Guests of the General Assembly}

The Thirty-fifth session of the Pioneer Lawmakers Association of Iowa reassembled in the State House at 2:00 p.m., March 26, 1959, and were escorted as a group into the chamber of the house of representatives as guests of the Fifty-eighth Iowa General Assembly meeting in joint convention. President Davidson and the featured speaker, former Governor Robert Blue, were seated at the speaker's desk with the presiding officer, Lieutenant Governor Edward J. McManus. The "joint convention for the purpose of participating in a program honoring the Pioneer Lawmakers" was called to order by the lieutenant governor who then introduced the majority leader of the senate, Jack Schroeder.

Mr. Schroeder: Gentlemen, I want to extend to each of you Pioneer Lawmakers of the State of Iowa a hearty welcome on behalf of your colleagues in the senate today. We are pausing today to pay tribute to you veteran legislators. You 
have set the pattern for many of the things that we are doing today.

We discuss many things today in the senate that I suppose many of you people discussed for many years-reapportionment. For many of you who come back and see the same issues year after year it probably gives you quite a pleasure to think back on the great contribution that you as individuals made to the State of Iowa. I think that you join with me in remembering your days in the legislature as probably some of your most cherished days. One of the most cherished honors that can come to any man or woman in this state is to serve with the fellowship and the dedication with which you have served in the past and with which we are attempting to serve in the present, representing the people of Iowa in this General Assembly.

We the lawmakers of today commend you, the lawmakers of yesterday, for the forthright and steadfast manner in which you came to grips with the problems which faced you in the Assemblies in which you served. We are delighted to have you return to these halls today and may God bless every one of you.

Lieutenant Governor McManus then presented the minority leader of the house, Representative Scott Swisher, who welcomed the Pioneer Lawmakers on behalf of that body:

"Pioneer," according to Webster's dictionary, means one "who goes before, as into the wilderness, preparing the way for others to follow." We pay tribute to those of you who have prepared the way for us to follow.

As each generation goes through youth to maturity, each experience is fresh and new, each happening is for the first time. For the parent who observes the child learning what the parent already knows, great indulgence is needed.

So it is between you Pioneer Lawmakers and those of us who occupy your chairs today. You know the problems we face, the satisfactions, the frustrations, the friendships. You battled fiscal matters; you obtained good schools for us; you helped make our institutions for higher education great; and you got us out of the mud. We ask your indulgence as we try to settle the same old issues. We can but hope that as Pioneer Lawmakers we will be as highly regarded as we regard you.

Welcome from the House.

The proceedings were turned over to the retiring president of the Pioneer Lawmakers, Judge Harold E. 
Davidson, who introduced the featured speaker of the session, former governor of Iowa, Robert D. Blue.

\section{Address By Governor Blue}

It is said that the two most important words that a man can ever utter are the two words "I believe." On these two words hinge the success or failure of all human endeavor. St. Paul states this basic truth in these words: "Now faith is the substance of things hoped for, the evidence of things not seen."

Humanity is caught between the cross fire of two powerful philosophies of government. One is the philosophy of individual capitalism, the other is the philosophy of governmental capitalism. We call it the cold war.

Some may think that it is something new. Actually, it is one of the oldest facts of life. It is a battle almost without beginning or end. Eliminate the names, the places, the dates, and you find the objectives the same. It is the eternal battle to control the mind of man, and by controlling his mind control his actions. The weapons are not new. Fear, hate, superstition, prejudice, greed, lies, slander and naked, brutal force are the ancient and the modern weapons of materialism and communism. Courage, love, knowledge, fair mindedness, generosity, truth and reason are the weapons of freedom and of a spiritually minded man.

Why am I saying these things to you? Because belief, or attitude, is the keystone on which every social, governmental, economic and religious institution-past, present and future-must rest. Challenged and threatened by communist ideology, fear to some extent rather than faith, is controlling the minds and the actions of our people today.

This nation was born in faith. The signers of the Declaration of Independence said: "With a firm reliance upon the protection of a divine providence, we mutually pledge to each other our lives, our fortunes and our sacred honor." And that indeed is what they gave to us. The attitude of Washington before that vital crossing of the Delaware is disclosed by the watchword of 
the night: "Victory or death." It was Lincoln's attitude as revealed in his words and his actions that saved this nation from dissolution.

A question has been raised as to how clear and how firm is the attitude of our younger generation about our form of government. Are we neglecting to emphasize to our own people and to those of other nations that modern capitalism is a totally different capitalism than the European capitalism of the day of Karl Marx, and how it is different?

We could profit by some self-criticism and discussion of the basic moral values and the social and economic processes upon which our society is founded. It is said that it is better to debate a matter, even though it is not settled, than to settle a matter without debate. I want to briefly discuss some of our attitudes and to restate some basic truths.

What is our attitude about government? Americans have great faith in law, but law is mere frozen morality. It is sterile, it is unproductive, it can never be a substitute for moral principle and the action of the individual. Legal morality may rest upon the shifting sands of expediency or the bedrock of individual and collective moral conscience.

As a legislator, you may base your vote primarily upon the next election and thus become the politician which the conscientious public scorns; or you may base your action upon the welfare of the next generation and become to a greater or lesser degree the statesman that the public reveres.

Good laws, my friends, merely make good government possible-they can never guarantee good government. The attitude of the administrator, therefore, becomes most important in the success of any law. Behind the administrator is the attitude of the public. The slaughter upon our highways will never end until the attitude of the public toward the motor vehicle is changed. The law which deters because of fear of a penalty is 
indeed a poor substitute for reverence for the commandment "Thou shalt not kill."

The attitude of the administrator is determined by his education, by his experience, and by public conscience. It therefore becomes a matter of vital importance in a representative government that every voter and every administrator be well grounded in the fundamental principles of government and of history. Although there is substantial improvement, a study of the required courses of instruction and those which are elective indicates that a large segment of our society are not getting this training. Let no one underestimate the importance of this matter, either to our national security or to good government.

It was the attitude of men like Benedict Arnold, Aaron Burr and others who placed personal advancement and gain over loyalty that from time to time has placed our national life in jeopardy. It was the attitude of self-sacrifice and loyalty of Adams, Washington, Lincoln, Wilson and Eisenhower and a host of others that has made and that has saved this nation. Law alone, such as law barring communism, will not save us. Neither will oaths of loyalty. Nevertheless, the attitude of students and scientists alike toward loyalty oaths is disturbing.

The president of the United States, as well as the notary public, must take an oath of loyalty. The witness in the court and the guardian of the minor likewise take an oath. Without loyalty, our nation will disintegrate.

We need a better understanding of the purpose of oaths. Intellectual liberty is being confused with license. Lincoln said: "The world has never had a good definition of the word 'liberty,' and the American people just now are much in need of one." In today's work, the attitude of the scientists can be as important as that of a president or a general.

What is our attitude toward education? Has it become a household god? It can help, but it alone can- 
not save us. A diploma is a poor substitute for knowledge and for good judgment.

I believe that the present policy of retaining the mentally slow child in school to learn what he can is good, but let's stop kidding the child and his parents. High school diplomas are often little more than certificates of attendance, rather than certificates of academic achievement. It might be well for us to consider giving diplomas for college entrance preparation and others for shop, agriculture, business practice and home making. It should be the basic purpose of school to provide an education rather than to provide a social and athletic center.

It is the attitude of the parents, and of business interests, rather than the attitude of the teachers, that has created the present situation. The public should recognize its responsibility. The schools will put forth greater effort on academic achievement when the attitude of the public demands such an emphasis.

During the recent months there has been building up a dangerous attitude toward agriculture. The public is being told by administrators, and the press, of the high cost. Only this week Iowa's own Leo Hoegh, Civil Defense Director, told me that the funds invested in strategic raw materials are nearly as great as the amount invested in surplus foods. But these comparisons are not being made public.

Agricultural costs are seldom compared with cost to the government of the high depreciation rates enjoyed by the oil industry, or the huge indirect subsidies given to both labor and industry in the form of defense contracts, and by both the social security and the unemployment acts. Agriculture has only recently become eligible for social security benefits, and still has no protection from unemployment.

While the unit price to the food producer has been decreasing, the processing cost per unit has been increasing. A large part of the near-stability in the cost of living has been achieved in a substantial degree at the 
expense of the farmer by reducing the sale price of the unit of unprocessed foods. No comparison is made for public consumption of the cost of obsolete armament, running into billions of dollars.

Public conscience is not offended by melting down an old battleship, but we are too close to the age-old problem of famine to consider corn and wheat as so much phosphate, potash and nitrogen, and return the surplus to the soil where the elements can be used again in accordance with the laws of nature to provide new food just as we melt down the old battleships to provide steel for fabrication into hundreds of new shapes.

The ambitions of our farm organizations and the single-track minds of our agricultural scientists are personally responsible for many of our agricultural problems. Unless their attitudes change, the producing farmer will continue to receive less than a fair share of the national income. Agriculture is a part of our complex social and economic system, both at the national and international level. We must cease considering it as a separate problem. Let the experts and the press spend more time discussing the inter-relationships of agriculture to our total economy and less time on the techniques of production.

The producing farmer cannot forever continue to exist in an economic structure where he must sell the product that he raises in a market governed by the law of supply and demand, and purchase the product for family consumption and business operation in a market where labor rates are determined by collective bargaining and the sale prices are determined by fair trade laws and oft-times the industrial leader and the labor leader act in collusion. He cannot continue to exist in an economic climate where the returns for his labor and his product are constantly being deflated in value, while the things he must buy are constantly being inflated in value. What part of the increase in the value of stock can be fairly attributed to the inequitable share of the 
national income received by the farmer for his product?

In recent years in Iowa the budget and financial control committee, which originated primarily as a study committee, has tended to usurp authority which belongs primarily to the Executive Council. There is a constant and natural jealousy between the legislative and executive branches of government. Too often the candidate for executive office is apt to campaign on the theory that he can change the law, as opposed to the doctrine that it is his province to propose needed changes and the basic responsibility of the legislature to enact the law. The public, unfortunately, tends to accept the former doctrine.

During the last several months the federal Supreme Court has found a number of its decisions under critical scrutiny. Criticism has come from no less distinguished bodies than the Association of Justices of the State Supreme Courts, and from the American Bar Association. The criticism is to the alleged attitude of the Court toward the rights of states to protect themselves in certain areas such as state legislation against subversive activities, the removal of the authority of the state and local governments in educational matters. and by the narrow legalistic construction of the Acts of Congress, and by sometimes placing what seems like undue emphasis and burdens upon law-enforcing officials in criminal cases while at the same time giving reasonable and proper protection to the rights of individuals in criminal cases where public security is involved.

Concededly, judicial interpretation of the statutes will contain a certain amount of legislative flavor, but it is of basic importance that the integrity of state governments be preserved and the proper prerogatives of the legislative branches of both the state and federal governments be conscientiously respected by the courts. This is an area in which we well can spend some time in self-examination of our attitudes.

The primary duty of any government is to maintain 
order at home, peace with other countries, and to provide an equitable and stable economic system. Inflation is a species of robbery. Men who would bitterly denounce the man who robs the poor box at the church or defrauds the widow and the orphan will unblushingly proclaim the justice of creeping inflation as a necessity of maintaining full employment, with, of course, the important by-product of winning the next election. I can justify mortgaging my future and the future of my children and my grandchildren to preserve our freedom, but I cannot justify a mortgage upon my future or their future in order to provide myself with present unearned luxuries or to avoid some degree of self-denial. Inflation plunged Germany into economic chaos after World War I. Every major city in the United States is confronted with budgetary problems. Certainly the practical bankruptcy of the wealthy State of Michigan should be a danger signal for all to heed.

Adam Smith, the father of economic science, said: "Where national debts have once been accumulated to a certain degree there is scarcely, I believe, a single instance of their having been fairly and completely paid. The liberation of the public revenue has always been brought about by bankruptcy; sometimes by an avowed one, but always by a real one, though frequently by a pretended payment. The raising of the denomination of the coin has been the most usual expedient by which a real public bankruptcy has been disguised under the appearance of pretended payment."

It is thought-provoking that while the Soviets are constantly increasing the use of the profit motive and devoting a large part of production to capital structure, the free world, through inflation, taxation, and security programs is reducing the incentive to work and to save.

Rome became the greatest power on earth, but she perished because of corruption and self-indulgence within. Every modern dictator has corrupted the people with their own tax money to maintain himself in power. 
What are we doing? What is our attitude toward appropriating by inflation the estates of widows, orphans and the aged, and the trust funds of our non-profit institutions in order to avoid paying for our luxuries today? What is the American attitude? Is government the servant and the people the master, or government the master and the people the servants? Shall the people support the government or the government support the people? Shall we pay lip service to private capitalism and practice state capitalism? Shall we profess belief in equality and practice segregation? Have we made our attitudes toward colonialism crystal clear to the people of Asia and Africa, or are we hedging because of our friendship with England and France? What the people of Africa and Asia believe is our position about colonialism is of vital importance to our success in Berlin, in the Middle East, and throughout the whole world.

Tomorrow is the anniversary of the passion and the death of the greatest man who ever lived. A single man, Jesus Christ, a lowly Judean carpenter, by his attitude changed and is changing the world in which we live. When he faced the hour of decision in the Garden of Gethsemane he prayed, "Oh, my Father, if this cup may not pass away from Me except I drink it, Thy will be done."

We may be the doubting Thomas, we may be the timid Peter, or we can become the courageous Peter, and we can become the rock upon which a world of freedom and a world of peace can be built.

America cannot accept the privileges of wealth and of world leadership without accepting the responsibilities of wealth and leadership. If the world is to be saved, if we are to be saved, our attitudes shall be as important or more important than our missiles. Yes, St. Paul was right, "Now faith is the substance of things hoped for, the evidence of things not seen." 
Copyright of Annals of Iowa is the property of State of Iowa, by \& through the State Historical Society of Iowa and its content may not be copied or emailed to multiple sites or posted to a listserv without the copyright holder's express written permission. However, users may print, download, or email articles for individual use. 